\title{
REAPing the Benefits: Development and Use of a Structured Evaluation Tool to Codify Learning Resources for Global Health Professionals
}

\author{
Meike Jill Schleiff ( $\nabla$ mschlei4@jhu.edu ) \\ Johns Hopkins University https://orcid.org/0000-0001-6492-3718 \\ Elizabeth Hahn \\ Johns Hopkins School of Public Health
}

Caroline Dolive

Sustaining Technical and Analytic Resources (STAR)

\section{Lillian James}

Johns Hopkins University Bloomberg School of Public Health

\section{Anant Mishra}

Johns Hopkins University Bloomberg School of Public Health

\section{Bhakti Hansoti}

Johns Hopkins School of Medicine, Department of Emergency Medicine

\section{Research article}

Keywords: Assessment, Competency, eLearning, Global Health, Leadership

Posted Date: February 26th, 2021

DOl: https://doi.org/10.21203/rs.3.rs-244845/v1

License: (1) This work is licensed under a Creative Commons Attribution 4.0 International License.

Read Full License

Version of Record: A version of this preprint was published at BMC Medical Education on July 8th, 2021. See the published version at https://doi.org/10.1186/s12909-021-02805-6. 


\section{Abstract}

Introduction: The learning opportunities for global health professionals have expanded rapidly in recent years. The diverse array of learners and wide range in course quality underscore the need for an improved course vetting process to better match learners with appropriate learning opportunities. Methods: We developed a structured tool to assess overall course quality by determining performance across four defined domains Relevance, Engagement, Access, and Pedagogy (REAP). We applied this tool across a learning catalogue developed for participants enrolled in the Sustaining Technical and Analytic Resources (STAR) project, a global health leadership training program. Results: The STAR learning activities database included a total of 382 courses, workshops, and web-based resources which fulfilled 531 competencies across three levels: core, content, and skill. Relevance: The majority of activities were at an understanding or practicing level across all competency domains (486/531, 91.5\%). Engagement: Many activities lacked any peer engagement $(202 / 531,38.0 \%)$ and had limited to no faculty engagement $(260 / 531,49.0 \%)$. Access: The plurality of courses across competencies were offered on demand $(227 / 531,42.7 \%)$ and were highly flexible in pace $(240 / 531,45.2 \%)$. Pedagogy: Of the activities that included an assessment, most matched activity learning objectives (217/531, 40.9\%). Discussion: Through applying REAP to the STAR project learning catalogue, we found many online activities lacked meaningful engagement with faculty and peers. Further development of structured online activities providing learners with flexibility in access, a range of levels of advancement for content, and opportunities to engage and apply learning are needed for the field of global health.

\section{Introduction}

A commitment to promoting societal health is perhaps one of the few unifying features of the global health and public health workforces.(Koplan et al., 2009; Jogerst et al., 2015) Those who work in the field approach their workplace challenges from different perspectives: as generalists and specialists; as academicians and field-based practitioners; as citizens of low- and middle-income countries (LMICs) and high-income countries; as advocates and clinicians. Professionals at all stages of their career can benefit from opportunities to further develop and expand their skills and knowledge. The challenge is finding the right opportunities that best meet both their goals and professional needs. Moreover, given the plethora of learning options available, it is unclear how one should evaluate opportunities for suitability (i.e., appropriate content) versus desired format (e.g. in-person versus online, or a hybrid of both) and engagement level (e.g. interactive workshops versus asynchronous courses).(R et al., 2018; Douglass et al., 2017)

Recent years have seen an exponential rise in the availability of massive open online courses (MOOCs) and a rapid expansion in content variety and the number of institutions offering global health courses. Making online courses relevant, impactful, and desirable to learners has required drawing insights from both learning theory and learner demand.(Aragon, 2002; Huang, 2002) However, despite improvements, increased attention is still needed to appropriately design courses that meet the skills and values sought by the diverse array of learners while still being actively engaging.(Huang, 2002; Merrill, 2013) For 
example, both young professional students as well as more "nontraditional" (e.g. mid-career and executive-level professionals) students have been found to place similar importance on how a course is assessed, but nontraditional students place greater importance on how well a course is designed, especially with regards to course expectations and instructions for accessing resources and support.. (Hixton et al., 2016) The differing values of learners, combined with the continually expanding array of online resources, underscore the need for a systematic approach to catalogue the myriad learning opportunities available for global health professionals, many of whom are busy and have "numerous responsibilities that compete for their time".(Hixton et al., 2016)

In recent years, as learning theories have been expanded to incorporate online education, a variety of course instruction rubrics have emerged as tools to help guide the development of new courses and better evaluate existing ones. Most of these rubrics have standards or indicators covering a general course overview and information, course design, learning objectives, accessibility, learner support, interaction and engagement, assessment, and technology (see Table 1 for a summary of the topics covered by several commonly used rubrics). For example, the Quality Matters (QM) rubrics, which have been tested and are widely utilized, outline eight general standards each with specific indicators. (Marylandonline, 2016-2020) Points are assigned to each indicator and then summed to create an overall assessment score. California State University, Chico's "Rubric for Online Instruction", which is informed by the Quality Matters rubrics, assesses courses across six categories.(California State University at Chico, 2019; https://www.csuchico.edu/eoi/_assets/documents/rubric.pdf, 2009) Within each category, standards are outlined for baseline, effective, and exemplary course criteria. Additional notable rubrics include the Illinois Online Network's "Quality Online Course Initiative (QOCI) Rubric" initially created in 1998 and updated in 2018 with best practices for online learning, which outlines seven categories for assessment and the University of Minnesota's “The Check: A Guide to Online Course Design," which provides twelve checklists for effective online courses.(Illinois Online Network, 2019)'(CEHD's Digital Education and Innovation Team, 2017) Both the rubrics developed by the California State University, Chico and the University of Minnesota specifically evaluate course communication between students and faculty, course communication between students themselves, and student feedback on the course. (CEHD's Digital Education and Innovation Team, 2017; California State University at Chico, 2019) These rubrics have similarities as well as some unique features; most were designed for quite specific kinds of learning activities and/or target audiences.

The Sustaining Technical and Analytic Resource (STAR) project is a global health training program for both junior and experienced global health professionals. Participants in the project provide technical support across a breadth of global health program areas to a variety of host institutions and are also provided with protected time and support for leadership training and professional development. STAR participants are based in the US and abroad and each participant is provided with an individualized learning plan that focuses on their individual development goals.(Hansoti et al., 2020) In order to facilitate identifying appropriate learning opportunities to match the needs of each unique participant, the STAR project built a database to catalogue hundreds of learning activities for participants across a 
diverse array of topic areas. We soon realized that the process of identifying, vetting, and assigning appropriate learning activities for a diverse pool of professionals was a more general obstacle for the field of global health to overcome. This paper outlines our process of developing a new tool to assess a variety of course quality indicators for use by the STAR project. The initial process of sourcing learning opportunities to develop our database and how that process has evolved as more participants came onto the program was also evaluated.

\section{Methods}

\section{Background - STAR Project}

The STAR project is a global health leadership training program, designed to support health-professionals in US and LMICs. Both the STAR curriculum and the cohorts are described in greater detail elsewhere. (Hansoti et al., 2020) These participants vary widely in their professional foci and backgrounds, with many focused on health programs in infectious disease (specifically tuberculosis or HIV/AIDS) and across a variety of technical areas (for example monitoring, evaluation, and learning (MEL) versus supply chain management). All STAR participants are provided with an individualized learning plan (ILP), based on their learning goals. In order to guide the baseline competency assessments, development of ILPs, and the organization of our database, a competency framework was developed for STAR (see Figure 1). (Hansoti et al., 2020) This framework included "core" competencies that all participants were expected to demonstrate a minimum level of expertise in by the end of the fellowship as well as elective technical and content competencies. Within each competency domain, a set of five milestones were defined which represented demonstrable knowledge or skills ranging from a basic level of inquiry to advanced mastery.

\section{Development of the REAP Tool}

We conducted an online review using Google, Google Scholar, PubMed, and the Education Resources Information Center (ERIC) for tools developed and implemented to assess course quality, particularly for online courses. Although STAR participants may also complete in-person courses, the rubrics we chose to look at primarily addressed online and blended courses as these were most likely to be the best fit for the majority of STAR participants and were where we anticipated finding the most variety in terms of the quality of these courses.

Based on the results of our search, we developed a tailored and systematic approach to vetting learning activities for STAR: The Relevance, Engagement, Access, and Pedagogy (REAP) tool (Figure 2). The Relevance domain of REAP focuses on how well the content covered in a course or other activity aligns with STAR's competency framework and milestone levels.(Hansoti et al., 2020) The Engagement domain focuses on the extent to which learners have opportunities to engage with each other and with course faculty. Within the Access domain, we capture key variables related to the format (online or onsite), pace, and flexibility of the learning activity. Finally, the Pedagogy domain captures elements of the course credibility and assessment approaches. 
Given the wide range of backgrounds, levels of experience, and work contexts of global health and public health professionals, no single combination of course characteristics (e.g. online, self-paced, and with limited engagement with peers) will universally be the most desirable or appropriate for all participants. The most useful approach, therefore, was to establish a standard review process that could determine whether a course would meet the needs of a specific participant. Particularly for STAR's diverse range of learners, we aimed not to determine definitively whether a course was "good" or "bad", but rather to examine the fit of a particular activity with individual learner preferences and needs across a set of variables. We also included a summary measure under each category of how good of a fit a particular learning activity was for STAR participants (for example, how well the Relevance variables for a particular activity aligned with the needs of STAR participants).

\section{Implementation of the REAP Tool}

We utilized the REAP tool to vet learning activities, including courses, workshops, and other activities, as they were entered into our learning activities database. Activities added to the database were identified through 1) an initial search for activities offered by STAR project partners and particularly focused on STAR core competencies(Hansoti et al., 2020) and 2) the specific areas of work and learning needs of STAR participants as they were onboarded. Each learning activity was reviewed by at least one STAR staff member and as much information as possible related to each REAP domain was added. The learning activity database is searchable by keyword as well as by select REAP indicators to locate opportunities that are the best fit for particular participants. Participant evaluations of learning activities are also accessible in the database so that participant satisfaction can be incorporated in the overall activity assessment.

Based on our experience using the tool, we made some revisions to improve clarity and efficiency of the tool as we went along. Two key changes were the addition of summary measures for each category in order to provide an overall assessment of the fit of an activity related to a particular category (e.g. Relevance) for the majority of STAR participants. Secondly, we streamlined the number of open text response variables in order to make the tool faster to use and to better standardize our data.

\section{Contents of the REAP-vetted Learning Activities Database}

The database is a live and active tool that was initially activated for STAR staff utilization in April 2019 and is added to continually. It contains a combination of workshops, courses (online and in-person), and web-based resources such as websites and grey literature reports and manuals. Of note, the contents of the database reflect the learning needs of STAR participants and are not meant to be representative of the overall learning opportunities for global health and public health professionals.

\section{Data Analysis}

Data for this paper were pulled from the active STAR database on June 16, 2020. Data from the database were analyzed using Stata v.15 (StataCorp LLC, College Station, TX, USA). A descriptive statistical 
approach was used to provide an overview of the learning activity database, characteristics of learning activities across each of the REAP domains, and the fit of each learning activity for STAR.

\section{Statement of IRB approval}

Ethical approval was sought and received from the institutional review boards of the Public Health Institute (IRB \#I19-022) and the Johns Hopkins Bloomberg School of Public Health (IRB00011259). Written consent was sought from all participants.

\section{Results}

A total of 382 activities were evaluated by the REAP tool of which there are 40 workshops (10.5\%), 280 Courses (73.3\%) and 62 web-based resources (22.1\%). Table 2 further describes the characteristics of the included learning activities. The majority of learning activities were offered online $(60 \%$ of workshops, $71.4 \%$ of courses, and $100 \%$ of web-based resources) and the majority of activities (85.1\%) fulfilled $1-2$ competencies. Most learning activities were based in the PAHO (84.8\%) or EURO (9.2\%) region, though some courses were also based in the AFRO region (3.4\%). Cost varied widely, with a large set of free courses $(47.1 \%)$, but also a substantial set of courses costing over $\$ 1,000(22.5 \%)$.

Each of the learning activities were further assessed across the four domains of the REAP tool. Results are displayed in Tables 3a-3d with key variables for each domain broken down by the category of competency (core, content, or skill-based competency). We chose these competency categories as a consistent way to analyze the REAP variables by domain because of the centrality of these competencies to the design of STAR's learning program and because we anticipated that some of the REAP variables would differ based on the kind of content that a learning activity focused on. Some activities were often able to fill multiple competencies and thus may be featured multiple times.

\section{Relevance}

The relevance findings, summarized in Table 3a, describe how the learning activities in the database were distributed across the three categories of STAR competencies (core, content, and skill) and by milestone level. Most courses across all competencies were either at the understanding $(195 / 531,36.7 \%)$ or practicing level $(291 / 531,54.8 \%)$. Very few courses were at the inquiring $(20 / 531,3.8 \%)$ or leading level $(2 / 531,0.4 \%)$..

\section{Engagement}

Engagement was a REAP domain that STAR participants prioritized, with general preferences for higher levels of engagement with faculty and peers (Table 3b). Among the core competency-related activities, there was a high level of faculty engagement (83/195, 42.6\%), but about equally as many had either no direct faculty engagement $(36 / 195,18.5 \%)$ or limited engagement $(41 / 195,21.0 \%)$. Faculty engagement levels also varied for the content and skill competencies, though skill competencies had a number of activities with average $(53 / 241,22.0 \%)$ and high levels of engagement $(50 / 241,20.7 \%)$. 
For peer engagement, many activities across all competency categories had no engagement (core: 60/195, 30.8\%; content: 45/95, 47.4\%; skill: 97/241, 40.2\%). For activities covering core competencies, the largest proportion of activities were characterized as having high levels of engagement $(66 / 195,33.8 \%)$. For content competency-related activities, the second largest set of courses had an average amount of peer engagement $(20 / 95,21.1 \%)$. Finally, the skill competency activities were fairly equally distributed across limited $(41 / 241,17.0 \%)$, average $(44 / 241,18.3 \%)$, and high $(45 / 241,18.7 \%)$ levels of engagement.

\section{Access}

Access variables include the in-person requirements of an activity and the flexibility in start time and pace (Table 3c). The largest proportion of courses were offered online only across all categories of competencies (core: 110/195, 56.4\%; content: 76/95, 80.0\%; skill: 173/241, 71.8\%). Core competencyrelated activities also had a large proportion (63/195, 32.3\%) offered in workshop or short training formats, while the content and skill competency-related activities had a small, but still noteworthy, number of these workshop format activities (content: 14/95, 14.7\%; skill53/241, 22.0\%).

For core competency activities, the flexibility in start time varied and was spread fairly evenly across infrequent starts (once or twice a year) $(47 / 195,24.1 \%)$, frequent starts $(53 / 195,27.2 \%)$, and on demand courses (available whenever learners signed up) (58/195, 28.7\%). Skill competencies followed a similar distribution, but with more courses $(106 / 241,44.0 \%)$ offered on demand. Content-related activities were more commonly available on demand $(63 / 95,66.3 \%)$.

Across competencies, the most common amount of flexibility in terms of the pace at which a participant could complete the course was "highly flexible" (core: 68/195, 34.9\%; content: 66/95, 69.5\%; skill: $106 / 241,44.0 \%)$.

\section{Pedagogy}

Table $3 d$ includes a set of variables related to activity pedagogy. For this variable, we evaluated the availability of a syllabus, the credibility of the instructor, the applied learning aspects, and use of assessment as a learning tool. Activities were split between which had and which did not have formal syllabi: core competency-related activities provided a syllabus $(93 / 195,47.7 \%)$ more often than not $(81 / 195,41.5 \%)$ and more skills activities also had a syllabus $(133 / 241,55.2 \%)$ than did not $(80 / 241$, $33.2 \%)$. The vast majority of instructors for all categories of activities were considered to be credible (core: 164/195, 84.1\%; content: 83/95, 87.4\%; skill: 203/241, 84.2\%).

The amount of application of knowledge and concepts in an activity was also a priority for STAR, with many participants valuing higher levels of applicability to both real-world examples and their work. The amount of applicability found within activities varied, but for many activities, there was not enough information about this aspect available (core: 45/195, 23.1\%; content: 22/95, 23.2\%; skill: 53/241, 22.0\%).

In terms of the inclusion and alignment of learner assessment within activities, both the core (88/195, $45.1 \%)$ and skill $(105 / 241,43.6 \%)$ competency-related activities had substantial proportions that included 
assessments that were highly aligned with activity learning objectives and topics. However, all categories of competencies had almost one third of activities for which the inclusion of any assessments was unknown (core: 56/195, 28.7\%; content: 31/95, 32.6\%; skill: 73/241, 30.3\%).

\section{Discussion}

The REAP tool presents a structured approach to codify learning activities in a systematic way. We were able to successfully apply the REAP tool to the STAR learning activities database and found it to be useful when identifying potential gaps and specific activities to meet learning needs of STAR participants. Our database, due to the needs of our participants, boosts a high volume of online learning resources. As such, we found that there are a large number of activities that had flexible pace and were easily accessible. This focus on online courses also meant that many of the activities were at an introductory level, syllabi were often not available, and a large number provide limited faculty or peer engagement opportunities.

The REAP tool adds to the available strategies designed to help educators and trainees sort through the plethora of available learning opportunities. As online education has expanded, educators have developed principles to guide the development of online learning. Effective online learning includes interactive and collaborative learning through synchronous discussions and reflections through asynchronous tools. Within these activities, instructors can create a safe and educational learning environment for learners by encouraging the development of critical thinking, monitoring discussion fora, and providing guidelines to ensure that course content and discussions are grounded in factual information.(Huang, 2002) In addition, online education needs to be both adaptable to the needs of diverse learners through varied formats to deliver content as well as flexible in order to allow learners to navigate content at their own pace.(Aragon, 2002) While these criteria are not novel, our analysis showed that many of the activities available to our participants lacked an emphasis on meaningful engagement and adopted a more passive approach to content delivery.

A central consideration in course design and evaluation is understanding the components students' value. Two past evaluations have found that services are needed to support learners based on their individual needs and that most students valued peer interaction and instructor feedback.(Ehlers, 2004)' (Young and Norgard, 2006) Our experience using REAP to identify learning activities for participants led us to recognize that there is still a lack of online courses that take full advantage of pedagogical and technological resources available to engage learners, which needs to be addressed in order to meet the needs presented in the literature as well as priorities voiced by STAR participants.

While this paper provides a practical example of how a structured evaluation tool can be used to codify learning activities, it is not without limitations. Principally, the activities in the STAR database do not represent the plethora of global health resources available, but rather a subset of activities that were chosen for STAR participants based on their individual goals and work needs. As such, this paper is not intended to be a comprehensive evaluation of global health learning opportunities, but rather a case 
example presenting how an innovative structured evaluation approach to identifying appropriate learning opportunities for diverse learners can be implemented as part of a global health training program.

As the STAR project continues, we hope to understand how well the REAP assessment of learning activities performed against learners' own evaluations of each learning activity that they completed. While the REAP tool does not serve as a formal assessment tool to determine which courses are "better" or "worse" (and thus will be unable to provide an approach to ranking activities), as a project, we found the use of this tool to be a useful exercise to allow us rapidly identify the core characteristics of an activity in a systematic, standardized way and match these with participants who required particular content, interaction with faculty and peers, level of flexibility in delivery mode, and applicability to their job and career goals.

\section{Declarations}

\section{Acknowledgements}

The co-authors appreciate the support from the Sustaining Technical and Analytic Resources (STAR) to undertake the work to develop the REAP tool and the database of learning activities leading to the data utilized in this paper. Further, we wish to thank STAR staff persons, including Melanie Atwell and Ashlee Walker, for their inputs on the participant process at STAR as well as in developing figures utilized in the paper, respectively.

\section{Funding}

The authors disclosed receipt of the following financial support for the research, authorship, and/or publication of this article: The STAR project is supported through Cooperative Agreement No.

7200AA18CA00001 by the United States Agency for International Development (USAID).

\section{Declaration of Conflicting Interests}

The authors declared no potential conflicts of interest with respect to the research, authorship, and/or publication of this article.

\section{Author Contributions}

MS and $\mathrm{BH}$ conceived the study design. MS, BH, $\mathrm{LJ}$, and $\mathrm{CD}$ developed the tools and database utilized in this paper and drafted portion of the manuscript's content. EH and AM conducted the analysis. All authors had a role in the synthesis and review of this manuscript.

\section{Data and Material Availability}

The data utilized for this analysis are available by contacting the STAR Project for further information. Data from the project are made available according to the United States Agency for International Development (USAID)'s Public Access Plan. 


\section{References}

Aragon, S. D. J. S. R. (2002) 'An Instructional Strategy Framework for Online Learning Environments'. Proceedings of the Academy for Human Resource Development, pp. 1022-1029.

California State University at Chico (2019) 'Exemplary Online Instruction'. Chico, California. Available at: https://www.csuchico.edu/eoi/ (Accessed: July 7, 2020).

CEHD's Digital Education and Innovation Team (2017) 'The Check: A Guide to Online Course Design'. University of Minnesota. Available at: https://academics.cehd.umn.edu/digital-education/wpcontent/uploads/2017/05/the-check.pdf?pdf=The-Check (Accessed: July 7, 2020).

Douglass, K., Jaquet, G., Hayward, A., Dreifuss, B. \& Tupesis, J. (2017). Development of a Global Health Milestones Tool for Learners in Emergency Medicine: A Pilot Project. Society for Academic Emergency Medicine.

Ehlers, U. (2004) 'Quality e-Learning from a Learner's Perspective'. Essen, Germany. Available at: https://www.eurodl.org/materials/contrib/2004/Online_Master_COPs.html (Accessed: August 20, 2020).

Hansoti, B., Schleiff, M., Akridge, A., Dolive, C., Gordon, A., et al. (2020). Developing a High-Impact Learning Program for Global Health Professionals: The STAR Project. Journal of Pedagogy and Health Promotion, 23-30.

Hixton, E., Barczyk, C., Ralston-Berg, P. \& Buckenmeyer, J. (2016). Online Course Quality: What to Nontraditional Students Value. Online Journal of Distance Learning, XIX (4).

https://www.csuchico.edu/eoi/_assets/documents/rubric.pdf (2009) 'Rubric for Online Instruction'. Available at: https://www.csuchico.edu/eoi/_assets/documents/rubric.pdf (Accessed: July 7, 2020).

Huang, H.-M. (2002). Toward Constructivism for Adult Learners in Online Learning Environments. British Journal of Educational Technology, 33 (1), 27-37.

Illinois Online Network (2019) 'Quality Online Course Initiative (QOCI) Rubric'. Available at: https://www.uis.edu/ion/resources/qoci/ (Accessed: July 7, 2020).

Jogerst, K., Callender, B., Adams, V., Evert, J., Fields, E., et al. (2015). Identifying interprofessional global health competencies for 21 st-century health professionals. Ann Glob Health, 81 (2), 239-47. DOI 10.1016/j.aogh.2015.03.006

Koplan, J. P., Bond, T. C., Merson, M. H., Reddy, K. S., Rodriguez, M. H., et al. (2009). Towards a common definition of global health. Lancet, 373 (9679), 1993-5. DOI 10.1016/S0140-6736(09)60332-9

Marylandonline (2016-2020) 'QualityMatters Rubrics and Standards'. Annapolis, MD, USA: MarylandOnline. Available at: https://www.qualitymatters.org/qa-resources/rubric-standards (Accessed: 
July 3, 2020).

Merrill, M. D. (2013) 'First principles of instruction: Identifying and designing effective, efficient and engaging instruction'. Hoboken, $\mathrm{NJ}$ : John Wiley and Sons.

R, R. M., Frank, E. \& Heller, R. (2018). Building public health capacity through online global learning. Open Praxis, 10 (1), 91-7.

Young, A. \& Norgard, C. (2006). Assessing the Quality of Online Courses from the Students' Perspective. Internet and Higher Education, 9, 107-115.

\section{Tables}




\begin{tabular}{|c|c|}
\hline Rubric & $\begin{array}{l}\text { Standard } \\
\text { Categories }\end{array}$ \\
\hline $\begin{array}{l}\text { Specific Review Standards from the Quality Maters (QM) Higher } \\
\text { Education Rubric, Sixth Edition }\end{array}$ & $\begin{array}{l}\text { - Course Overview and } \\
\text { Introduction } \\
\text { - Learning Objectives } \\
\text { (Competencies) } \\
\text { - Assessment and } \\
\text { Measurement } \\
\text { - Instructional } \\
\text { Materials } \\
\text { - Learning Activities } \\
\text { and Learner } \\
\text { Interaction } \\
\text { - Course Technology } \\
\text { - Learner Support } \\
\text { - Ascessibility and } \\
\text { Usability }\end{array}$ \\
\hline California State University, Chico Rubric for Online Instruction & $\begin{array}{l}\text { - Learner Support \& } \\
\text { Resources } \\
\text { - Online Organization } \\
\text { \& Design } \\
\text { - Instructional Design } \\
\text { \& Delivery } \\
\text { - A\$sessment \& } \\
\text { Eyaluation of Student } \\
\text { Learning } \\
\text { - Innovative Teaching } \\
\text { with Technology } \\
\text { - Faculty Use of } \\
\text { Student Feedback }\end{array}$ \\
\hline $\begin{array}{l}\text { Illinois Online Network (ION) Quality Online Course Initiative } \\
\text { (QOCI) }\end{array}$ & $\begin{array}{l}\text { - Instructional Design } \\
\text { - Communication, } \\
\text { Interaction, and } \\
\text { Collaboration } \\
\text { - Student Evaluation \& } \\
\text { A\$sessment } \\
\text { - Learner Support and } \\
\text { Resources } \\
\text { - Instructional } \\
\text { Materials \& } \\
\text { Technologies } \\
\text { - Accessibility } \\
\text { - Course Evaluation }\end{array}$ \\
\hline $\begin{array}{l}\text { University of Minnesota College of Education and Human } \\
\text { Development Digital Education and Innovation Team The Check: } \\
\text { Guide to Online Course Design }\end{array}$ & $\begin{array}{l}\text { A Course Information } \\
\text { - Course Design } \\
\text { - Graphic Design } \\
\text { - Student Support } \\
\text { - Learning Objectives } \\
\text { - Activities \& } \\
\text { A\$signments } \\
\text { - A\$sessment/Grading } \\
\text { - Materials \& Media }\end{array}$ \\
\hline
\end{tabular}


- Adcessibility \& Universal Design

- Course Communication

- Learning Technologies

- Course Evaluation

Table 1: Summary of key standards of commonly used course assessment rubrics 


\begin{tabular}{|c|c|c|c|c|}
\hline & $\begin{array}{c}\text { Workshop } \\
(\mathrm{n}=40)\end{array}$ & $\begin{array}{l}\text { Courses } \\
(\mathrm{n}=280)\end{array}$ & $\begin{array}{c}\text { Web-based } \\
\text { Resources } \\
(\mathrm{n}=62)\end{array}$ & $\begin{array}{c}\text { Total } \\
(\mathrm{N}=382)\end{array}$ \\
\hline $\begin{array}{l}\text { Course Location } \\
\text { Online }\end{array}$ & \multirow{2}{*}{$\begin{array}{c}24 \\
(60.0 \%) \\
9(22.5 \%) \\
6(15.0 \%) \\
1(2.5 \%) \\
\end{array}$} & \multirow{2}{*}{$\begin{array}{c}200 \\
(71.4 \%) \\
71(25.4 \%) \\
5(1.8 \%) \\
4(1.4 \%) \\
\end{array}$} & $62(100.0 \%)$ & 286 (74.9\%) \\
\hline $\begin{array}{l}\text { In-person } \\
\text { Either } \\
\text { Unknown }\end{array}$ & & & $\begin{array}{l}0(0.0 \%) \\
0(0.0 \%) \\
0(0.0 \%)\end{array}$ & $\begin{array}{c}80(20.9 \%) \\
11(2.9 \%) \\
5(1.3 \%)\end{array}$ \\
\hline $\begin{array}{l}\text { Fulfills Competency Categories } \\
\text { Core }\end{array}$ & \multirow{3}{*}{$\begin{array}{c}29 \\
(72.5 \%) \\
19 \\
(47.5 \%) \\
5(12.5 \%) \\
\end{array}$} & \multirow{3}{*}{$\begin{array}{c}151 \\
(53.9 \%) \\
188 \\
(67.1 \%) \\
69(24.6 \%) \\
\end{array}$} & $15(24.2 \%)$ & $195(51.0 \%)$ \\
\hline Skill & & & 34 (54.8\%) & $241(63.1 \%)$ \\
\hline Content & & & $21(33.9 \%)$ & $95(24.9 \%)$ \\
\hline $\begin{array}{l}\text { Number of Competencies } \\
\text { Fulfilled }\end{array}$ & \multirow{6}{*}{$\begin{array}{c}0(0.0 \%) \\
12 \\
(32.5 \%) \\
20 \\
(50.0 \%) \\
4(10.0 \%) \\
1(2.5 \%) \\
1(2.5 \%) \\
1(2.5 \%) \\
\end{array}$} & \multirow{6}{*}{$\begin{array}{c}1(0.4 \%) \\
145 \\
(51.8 \%) \\
87(31.1 \%) \\
\\
22(7.9 \%) \\
16(5.7 \%) \\
6(2.1 \%) \\
3(1.1 \%) \\
\end{array}$} & & \\
\hline $\begin{array}{l}0 \\
1\end{array}$ & & & $\begin{array}{c}1(1.6 \%) \\
47(75.8 \%)\end{array}$ & $\begin{array}{c}2(0.5 \%) \\
205(53.7 \%)\end{array}$ \\
\hline 2 & & & $13(21.0 \%)$ & $120(31.4 \%)$ \\
\hline 3 & & & $0(0.0 \%)$ & $26(6.8 \%)$ \\
\hline $\begin{array}{l}4 \\
5\end{array}$ & & & $1(1.6 \%)$ & $18(4.7 \%)$ \\
\hline $\begin{array}{l}5 \\
6\end{array}$ & & & $0(0.0 \%)$ & $4(1.1 \%)$ \\
\hline WHO Region & \multirow{6}{*}{$\begin{array}{c}0(0.0 \%) \\
2(5.0 \%) \\
38 \\
(95.0 \%) \\
0(0.0 \%) \\
0(0.0 \%) \\
0(0.0 \%) \\
\end{array}$} & \multirow{6}{*}{$\begin{array}{c}13(4.6 \%) \\
24(8.6 \%) \\
238 \\
(85.0 \%) \\
3(1.1 \%) \\
2(0.7 \%) \\
0(0.0 \%) \\
\end{array}$} & & \\
\hline $\begin{array}{l}\text { AFRO } \\
\text { EURO }\end{array}$ & & & $\begin{array}{c}0(0.0 \%) \\
9(14.5 \%)\end{array}$ & $\begin{array}{l}13(3.4 \%) \\
35(9.2 \%)\end{array}$ \\
\hline PAHO & & & $48(77.4 \%)$ & $324(84.8 \%)$ \\
\hline SEARO & & & $1(1.6 \%)$ & $4(1.1 \%)$ \\
\hline WPRO & & & $0(0.0 \%)$ & $2(0.5 \%)$ \\
\hline Unknown & & & $4(6.5 \%)$ & $4(1.1 \%)$ \\
\hline \multirow{2}{*}{$\begin{array}{l}\text { Cost } \\
\$ 0 \text { (Free) }\end{array}$} & \multirow{6}{*}{$\begin{array}{c}6(15.0 \%) \\
0(0.0 \%) \\
4(10.0 \%) \\
8(20.0 \%) \\
21 \\
(52.5 \%) \\
1(2.5 \%) \\
\end{array}$} & \multirow{6}{*}{$\begin{array}{c}117 \\
(41.8 \%) \\
46(16.4 \%) \\
32(11.4 \%) \\
12(4.3 \%) \\
65(23.2 \%) \\
8(2.9 \%) \\
\end{array}$} & & \\
\hline & & & $57(91.9 \%)$ & $180(4 \% .1 \%)$ \\
\hline $\begin{array}{l}\$ 1-\$ 99 \\
\$ 100-\$ 499\end{array}$ & & & $0(0.0 \%)$ & $46(12.0 \%)$ \\
\hline $\begin{array}{l}\$ 100-\$ 499 \\
\$ 500-\$ 999\end{array}$ & & & $\begin{array}{l}1(1.0 \%) \\
0(0.0 \%)\end{array}$ & $20(5.2 \%)$ \\
\hline & & & $0(0.0 \%)$ & $86(22.5 \%)$ \\
\hline Unknown & & & $4(6.45 \%)$ & 13 (3.4\%) \\
\hline $\begin{array}{l}\text { Activity Hours } \\
<20\end{array}$ & \multirow{3}{*}{$\begin{array}{c}29 \\
(72.5 \%) \\
4(10.0 \%) \\
7(17.5 \%) \\
\end{array}$} & \multirow{3}{*}{$\begin{array}{c}158 \\
(56.4 \%) \\
47(16.8 \%) \\
75(26.8 \%) \\
\end{array}$} & $31(50.0 \%)$ & $218(57.1 \%)$ \\
\hline $\begin{array}{l}20-40 \\
\geq 40\end{array}$ & & & $\begin{array}{l}11(17.7 \%) \\
20(32.3 \%)\end{array}$ & $62(16.2 \%)$ \\
\hline Top 5 Institutions & & & & \\
\hline $\begin{array}{l}\text { Johns Hopkins University } \\
\text { American Management Assoc. }\end{array}$ & $\begin{array}{c}2(5.0 \%) \\
21 \\
(52.5 \%)\end{array}$ & $\begin{array}{c}30(10.7 \%) \\
13(4.6 \%)\end{array}$ & $\begin{array}{l}3(4.8 \%) \\
0(0.0 \%)\end{array}$ & $\begin{array}{l}35(9.2 \%) \\
34(8.9 \%)\end{array}$ \\
\hline Coursera & $0(0.0 \%)$ & $29(10.4 \%)$ & $0(0.0$ & 29 (7.6\%) \\
\hline $\begin{array}{l}\text { USAID University } \\
\text { World Health Organization }\end{array}$ & $\begin{array}{l}0(0.0 \%) \\
3(7.5 \%)\end{array}$ & $\begin{array}{l}24(8.6 \%) \\
10(3.6 \%)\end{array}$ & $\begin{array}{l}0(0.0 \%) \\
3(4.8 \%)\end{array}$ & $\begin{array}{l}246.3 \%) \\
16(4.2 \%)\end{array}$ \\
\hline & & & & \\
\hline
\end{tabular}

Cells highlighted blue signify the highest proportion. STAR, Sustaining Technical and Analytical Resources

Table 2. Characteristics of STAR learning database activities 


\begin{tabular}{|c|c|c|c|c|}
\hline & $\begin{array}{c}\text { Core } \\
\text { Competencies } \\
(\mathrm{n}=195)\end{array}$ & $\begin{array}{c}\text { Content } \\
\text { Competencies } \\
(\mathrm{n}=95)\end{array}$ & $\begin{array}{c}\text { Skill } \\
\text { Competencies } \\
(\mathrm{n}=241)\end{array}$ & Total \\
\hline $\begin{array}{l}\text { Milestones } \\
\text { Inquiring }\end{array}$ & $\begin{array}{c}4(2.0 \%) \\
74(38.0 \%)\end{array}$ & $\begin{aligned} 3 & (3.2 \%) \\
32 & (33.7 \%)\end{aligned}$ & $\begin{array}{c}13(5.4 \%) \\
89(36.9 \%)\end{array}$ & $\begin{array}{c}20 \\
195\end{array}$ \\
\hline $\begin{array}{c}\text { Understanding } \\
\text { Practicing } \\
\text { Leading } \\
\text { Advancing }\end{array}$ & $\begin{array}{c}106(54.4 \%) \\
10(5.1 \%) \\
1(0.5 \%)\end{array}$ & $\begin{array}{c}53(55.8 \%) \\
7(7.4 \%) \\
0(0.0 \%)\end{array}$ & $\begin{array}{c}132(54.8 \%) \\
6(2.5 \%) \\
1(0.4 \%)\end{array}$ & $\begin{array}{c}291 \\
23 \\
2\end{array}$ \\
\hline
\end{tabular}

REAP, Relevance, Engagement, Access, and Pedagogy. STAR, Sustaining Technical and Analytic Resources

Table 3a. REAP Relevance components by STAR competency category

Table 3b. REAP Engagement components by STAR competency category

\begin{tabular}{|l|c|c|c|c|}
\hline & $\begin{array}{c}\text { Core } \\
\text { Competencies } \\
(\mathrm{n}=195)\end{array}$ & $\begin{array}{c}\text { Content } \\
\text { Competencies } \\
(\mathrm{n}=95)\end{array}$ & $\begin{array}{c}\text { Skill } \\
\text { Competencies } \\
(\mathrm{n}=241)\end{array}$ & Total \\
\hline Faculty & & & & \\
Engagement & $36(18.5 \%)$ & $38(40.0 \%)$ & $65(27.0 \%)$ & 139 \\
None & $41(21.0 \%)$ & $20(21.0 \%)$ & $60(24.9 \%)$ & 121 \\
Limited & $27(13.9 \%)$ & $18(19.0 \%)$ & $53(22.0 \%)$ & 98 \\
Average & $4(2.1 \%)$ & $2(2.1 \%)$ & $9(3.7 \%)$ & 15 \\
Variable & $83(42.6 \%)$ & $14(14.7 \%)$ & $50(20.7 \%)$ & 147 \\
High & $4(2.1 \%)$ & $3(3.2 \%)$ & $4(1.7 \%)$ & 11 \\
Unknown & $60(30.8 \%)$ & $45(47.4 \%)$ & $97(40.2 \%)$ & 202 \\
\hline Peer Engagement & $26(13.3 \%)$ & $12(12.6 \%)$ & $41(17.0 \%)$ & 79 \\
None & $31(15.9 \%)$ & $20(21.1 \%)$ & $44(18.3 \%)$ & 95 \\
Limited & $9(4.6 \%)$ & $0(0.0 \%)$ & $8(3.3 \%)$ & 17 \\
Average & $66(33.8 \%)$ & $14(14.7 \%)$ & $45(18.7 \%)$ & 125 \\
Variable & $3(1.5 \%)$ & $4(4.2 \%)$ & $6(2.5 \%)$ & 13 \\
High & Unknown & & & \\
Unkn)
\end{tabular}

Cells highlighted blue signify the highest proportion

REAP, Relevance, Engagement, Access, and Pedagogy. STAR, Sustaining Technical and Analytic Resources

Table 3c. REAP Access components by STAR competency category 


\begin{tabular}{|c|c|c|c|c|}
\hline & $\begin{array}{c}\text { Core } \\
\text { Competencies } \\
(\mathrm{n}=195)\end{array}$ & $\begin{array}{c}\text { Content } \\
\text { Competencies } \\
(\mathrm{n}=95) \\
\end{array}$ & $\begin{array}{c}\text { Skill } \\
\text { Competencies } \\
(\mathrm{n}=241)\end{array}$ & Total \\
\hline \multicolumn{5}{|l|}{ In-person } \\
\hline \multirow{2}{*}{$\begin{array}{l}\text { requirements } \\
\text { Full } \\
\text { semester/term }\end{array}$} & $13(6.7 \%)$ & $3(3.2 \%)$ & 7 (2.9\%) & 23 \\
\hline & $63(32.3 \%)$ & $14(14.7 \%)$ & $53(22.0 \%)$ & 130 \\
\hline \multirow{2}{*}{$\begin{array}{l}\text { Workshop/training } \\
\text { Optional } \\
\text { Online only }\end{array}$} & $9(4.6 \%)$ & $2(2.1 \%)$ & & 19 \\
\hline & $110(56.4 \%)$ & $76(80.0 \%)$ & $173(71.8 \%)$ & $\begin{array}{l}19 \\
359\end{array}$ \\
\hline Unknown & $0(0.0 \%)$ & $0(0.0 \%)$ & $0(0.0 \%)$ & 0 \\
\hline \multicolumn{5}{|l|}{ Start flexibility } \\
\hline Frequent start & $53(27.2 \%)$ & $2(2.1 \%)$ & $42(17.4 \%)$ & 97 \\
\hline Open enrollment & $31(15.9 \%)$ & $9(9.5 \%)$ & $33(13.7 \%)$ & 73 \\
\hline $\begin{array}{l}\text { On demand } \\
\text { Unknown }\end{array}$ & $58(28.7 \%)$ & $63(66.3 \%)$ & $106(44.0 \%)$ & 227 \\
\hline $\begin{array}{c}\text { Unknown } \\
\text { Pace flexibility }\end{array}$ & 6 (3 1\%) & \multicolumn{2}{|c|}{ Pace flexibility } & 13 \\
\hline $\begin{array}{l}\text { Pace IIexibinly } \\
\text { Fixed pace }\end{array}$ & $52(26.7 \%)$ & $19(20.0 \%)$ & $58(24.1 \%)$ & 129 \\
\hline $\begin{array}{l}\text { Designated } \\
\text { schedule }\end{array}$ & $44(22.6 \%)$ & $2(2.1 \%)$ & $32(13.3 \%)$ & 78 \\
\hline with own pace & \multicolumn{4}{|c|}{$\begin{array}{l}\text { schedule } \\
\text { with own pace }\end{array}$} \\
\hline $\begin{array}{l}\text { Flexible } \\
\text { Highly flexible }\end{array}$ & $\begin{array}{l}25(12.8 \%) \\
68(34.9 \%)\end{array}$ & $\begin{array}{c}6(6.3 \%) \\
66 \text { (69.5\%) }\end{array}$ & $\begin{array}{c}38(15.8 \%) \\
106(44.0 \%)\end{array}$ & $\begin{array}{c}69 \\
240\end{array}$ \\
\hline Unknown & $6(3.1 \%)$ & $2(2.1 \%)$ & $7(2.9 \%)$ & 15 \\
\hline
\end{tabular}

Cells highlighted blue signify the highest proportion

REAP, Relevance, Engagement, Access, and Pedagogy. STAR, Sustaining Technical and Analytic Resources

\begin{tabular}{|c|c|c|c|c|}
\hline & $\begin{array}{c}\text { Core } \\
\text { Competencies } \\
(\mathrm{n}=195) \\
\end{array}$ & $\begin{array}{c}\text { Content } \\
\text { Competencies } \\
(\mathrm{n}=95) \\
\end{array}$ & $\begin{array}{c}\text { Skill } \\
\text { Competencies } \\
(\mathrm{n}=241) \\
\end{array}$ & Total \\
\hline $\begin{array}{l}\text { Syllabus } \\
\text { Provided } \\
\text { Not provided } \\
\text { Unknown }\end{array}$ & $\begin{array}{l}93(47.7 \%) \\
81(41.5 \%) \\
21(10.8 \%)\end{array}$ & $\begin{array}{l}37(38.9 \%) \\
38(40.0 \%) \\
20(21.1 \%)\end{array}$ & $\begin{array}{c}133(55.2 \%) \\
80(33.2 \%) \\
28(11.6 \%)\end{array}$ & $\begin{array}{l}263 \\
199 \\
69\end{array}$ \\
\hline $\begin{array}{l}\text { Instructor Credibility } \\
\text { Credible } \\
\text { Unknown/Not } \\
\text { credible } \\
\end{array}$ & $\begin{array}{c}164(84.1 \%) \\
31(15.9 \%)\end{array}$ & $\begin{array}{l}83(87.4 \%) \\
12(12.6 \%)\end{array}$ & $\begin{array}{c}203(84.2 \%) \\
38(15.8 \%)\end{array}$ & $\begin{array}{c}450 \\
81\end{array}$ \\
\hline $\begin{array}{l}\text { Activity Application } \\
\text { High } \\
\text { Average } \\
\text { Limited } \\
\text { None } \\
\text { Unknown } \\
\end{array}$ & $\begin{array}{l}27(13.9 \%) \\
56(28.7 \%) \\
56(28.7 \%) \\
11(5.6 \%) \\
45(23.1 \%) \\
\end{array}$ & $\begin{array}{l}6(6.3 \%) \\
17(17.9 \%) \\
36(37.9 \%) \\
14(14.7 \%) \\
22(23.2 \%) \\
\end{array}$ & $\begin{array}{c}27(11.2 \%) \\
37(15.3 \%) \\
106(44.0 \%) \\
18(7.5 \%) \\
53(22.0 \%) \\
\end{array}$ & $\begin{array}{l}60 \\
110 \\
198 \\
43 \\
120 \\
\end{array}$ \\
\hline $\begin{array}{l}\text { Assessment Inclusion } \\
\text { Aligned } \\
\text { Misaligned } \\
\text { Unexplained } \\
\text { Not included } \\
\text { Inclusion Unclear }\end{array}$ & $\begin{array}{c}88(45.1 \%) \\
4(2.1 \%) \\
18(9.2 \%) \\
29(14.9 \%) \\
56(28.7 \%) \\
\end{array}$ & $\begin{array}{l}24(25.3 \%) \\
0(0.0 \%) \\
16(16.8 \%) \\
24(25.3 \%) \\
31(32.6 \%) \\
\end{array}$ & $\begin{array}{c}105(43.6 \%) \\
1(0.4 \%) \\
25(10.4 \%) \\
37(15.3 \%) \\
73(30.3 \%) \\
\end{array}$ & $\begin{array}{c}217 \\
5 \\
59 \\
90 \\
160 \\
\end{array}$ \\
\hline
\end{tabular}

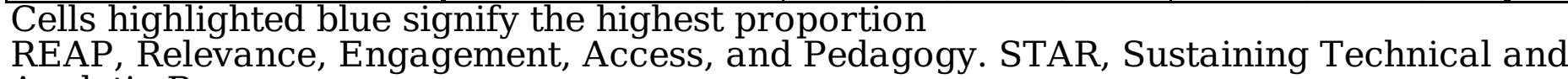
Analytic Resources 


\section{Table 3d. REAP Pedagogy components by STAR competency category}

\section{Figures}

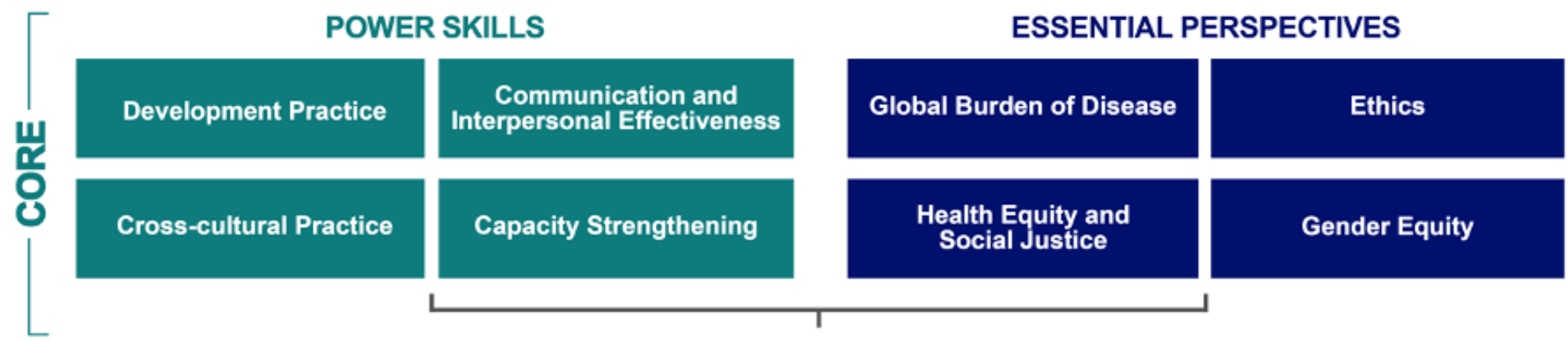

FELLOWS AIM TO ACHIEVE PRACTICING LEVEL; INTERNS AIM TO ACHIEVE UNDERSTANDING LEVEL

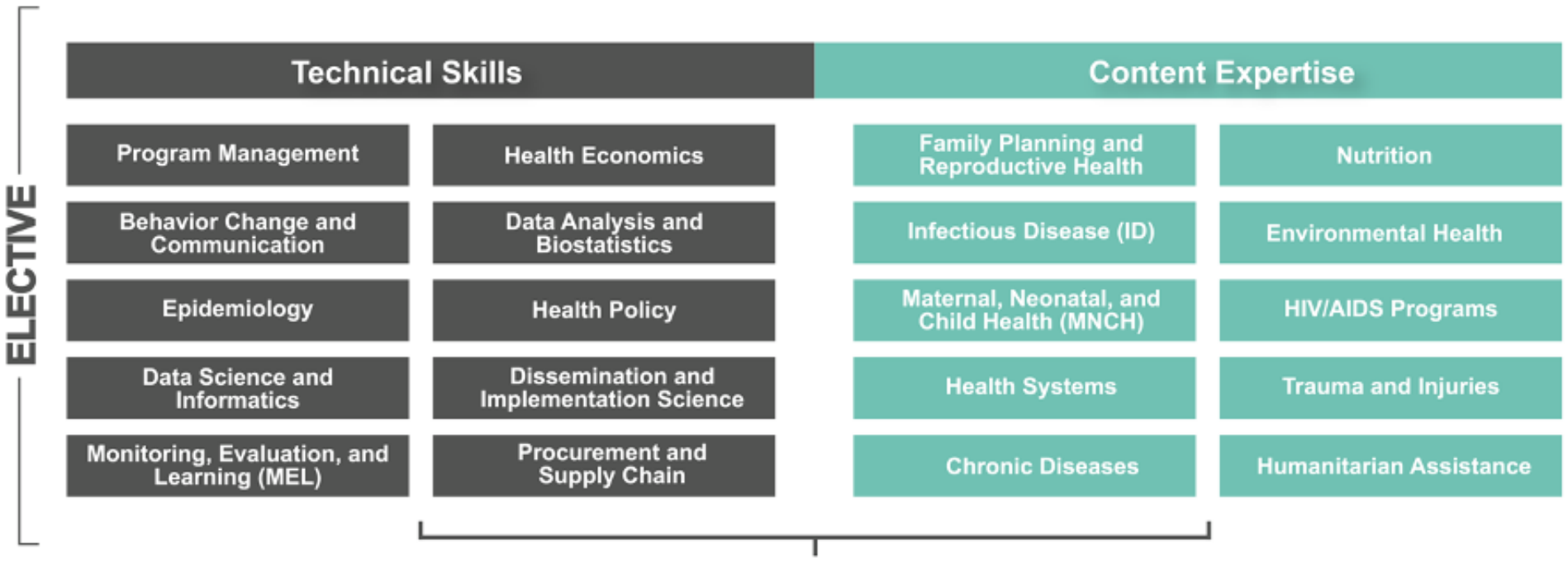

SELECT 2-4 ELECTIVE COMPETENCIES BASED ON KNOWLEDGE GAPS, SCOPE OF WORK, AND INTEREST

Figure 1

STAR Global Health Competencies Framework 


\section{General information:}

- Activity type and title

- Cost, location, online/onsite, hours to complete

- Accreditation/credentials offered

\begin{tabular}{|c|c|}
\hline $\begin{array}{l}\text { Relevance: } \\
\text { - Competency(ies) covered } \\
\text { - Milestone level }\end{array}$ & $\begin{array}{l}\text { Engagement: } \\
\text { - Interaction with peers } \\
\text { - Interaction with faculty }\end{array}$ \\
\hline $\begin{array}{l}\text { Access: } \\
\text { - In-person requirements } \\
\text { - Flexibility in start time/pace } \\
\text { - Platform characteristics/support }\end{array}$ & $\begin{array}{l}\text { Pedagogy: } \\
\text { - Syllabus available/instructor } \\
\text { - Assessments included } \\
\text { - Applied nature of the activity }\end{array}$ \\
\hline
\end{tabular}

REAP, Relevance, Engagement, Access, and Pedagogy

\section{Figure 2}

Key Variables Captured Within Each REAP Domain 